\title{
Determinants of Commercial Banks' Profitability in Malaysia
}

\author{
Ivan D. TROFIMOV1 \\ Nazaria MD ARIS 2 \\ Jovena Kho YING YING ${ }^{3}$
}

\begin{abstract}
This study aims to examine the relationship between non-performing loans (NPLs) and commercial banks' performance in Malaysia, alongside other factors. It considers the effect of NPLs, cost efficiency and bank size on commercial banks' profitability by using panel data regression (Pooled OLS model), covering the period of 2010-2015. The findings of the study show that NPLs and cost efficiency have a significant negative relationship with commercial banks' performances in Malaysia. On the other hand, bank size is found to have a significant positive relation with commercial banks' performances in Malaysia. Several policy and strategic implications are outlined: the continuing need to manage credit risk, reduction of non-core lending activities, improvement of systems transparency, cost control, and more lenient competition and anti-trust policies.
\end{abstract}

KEYWORDS: bank, non-performing loan, profitability.

JEL CLASSIFICATION: $C 23, G 21, G 28$

\section{INTRODUCTION}

Over the past two decades, following the Asian Crisis of 1997-98, the Malaysian banking sector has been subject to multidirectional and conflicting developments. On one hand, deregulation, greater competitive pressures from overseas players, disintermediation, and the shift by consumers towards high yielding deposits have posed challenges to Malaysian banks and undermined their profitability. On the other hand, solid economic growth, the strengthening of the middle class, and the rise of consumer culture have had positive effects on profits. Technological and financial innovation have reduced profit margins, but improvements in operational efficiency have had a positive impact on profits (Guru, 2002).

Most recently, Malaysia's banking sector has remained strong and resilient through the everchanging economic environment: despite a weak energy sector, subdued aggregate demand, certain quality deterioration from the overseas and commodity-related and real estate portfolios, capital and liquidity continue to cushion the negative influences. Combined with tough prudential regulations, this has resulted in a low level of impaired loans (Sufian, 2009; Standard \& Poors, 2017). Despite this, it is acknowledged that adverse changes in the international financial markets, increased volatility in Malaysian currency, and other 'black swan' events may reverse favourable trends and lead to the accumulation of non-performing loans (NPLs).

\footnotetext{
${ }^{1}$ Kolej Yayasan Saad (KYS) Business School, Malaysia, ivan.trofimov1@gmail.com (Corresponding author)

${ }^{2}$ University of Malaysia - Sarawak, Malaysia, nazzoes@gmail.com.

${ }^{3}$ University of Malaysia - Sarawak, Malaysia, jktt_tang@ hotmail.com.
} 
Given these conflicting tendencies, and considering that Malaysian banks were severely affected by the Asian Crisis and more recently the global financial crisis of 2007-8 (Khoon \& Mah-Hui, 2010), analysis of the levels and determinants of the banking profitability remains salient. It is well recognized in the literature that a stable and profitable banking system is a key to stable economy and growth (Abd Karim, Sok \& Hassan, 2010; Jokipii \& Monnin, 2013; Klein \& Weill, 2017), and Malaysia is not likely to be an exception.

The purpose of this study is to examine the relationship between the profitability of the key commercial banks in Malaysia and the level of NPLs during 2010-2015, controlling for two other determinants (cost efficiency and the size of the banks). The majority of previous studies of banking profitability in Malaysia covered earlier periods (prior to Asian Crisis or GFC), considered the effects of broader macroeconomic or industry factors on profitability, and did not look at the value of NPL when internal determinants of profitability were concerned. The working hypothesis is that there is a negative relationship between the value of NPLs and profitability, but a positive relationship between the degree of cost efficiency and bank size on one hand and profitability on the other. A panel data econometric model is used, based on financial data pertaining to Malaysian commercial banks.

The paper is organized as follows. Section 2 presents the literature review. The econometric method, data sources and empirical results are described in Section 3. Section 4 presents the concluding remarks and a discussion of policy implications.

\section{LITERATURE REVIEW}

Studies of the determinants of bank performance fall largely into two categories: analyses of banking sector efficiency, and analyses of banking sector profitability. The former fall outside of the scope of this paper; however, efficiency does contribute to higher profitability, and these two aspects of performance are intertwined. We refer to studies of the efficiency of the UK banking sector (Drake, 2001; Webb, 2003) and the analyses of commercial bank efficiency in transition economies (Grigorian \& Manole, 2006). The latter includes foreign ownership, prudential regulation tightening, and consolidation of the banking sector as principal determinants of efficiency, and show that foreign ownership and consolidation enhance efficiency, whilst prudential regulation effects vary across economies and prudential norms.

A large number of the studies of banking sector profitability concerned individual economies: the US (Berger, 1995), Australia (Pasiouras et al., 2006), Greece (Kosmidou, 2008), Colombia (Barajas et al., 1999), Brazil (Afanasieff et al., 2002) and Tunisia (Ben Naceur, 2003). The multi-country studies included Molyneux and Thorton (1992) and Pasiouras and Kosmidou (2007), which investigated bank profitability determinants in a sample of European economies; Hassan and Bashir (2003), who considered profitability of Islamic banks in 21 countries; and Demirguc-Kunt and Huizinga (1999), who analysed the influence of macroeconomic and institutional determinants on bank interest margins in 80 different economies. A number of hypotheses pertaining to bank profitability were considered.

Firstly, the effects of private versus public ownership of the banks were examined, with private ownership presumably leading to the implementation of more efficient policies and higher profitability. This hypothesis was confirmed by Beck et al. (2005) in their study of Nigerian banks, but rejected by Dietrich and Wanzenried (2011) in a study of Swiss banks. 
Secondly, the size of the board was hypothesized to negatively affect efficiency and profitability, as large boards do not favour good communication and decision-making processes. This hypothesis was verified for banking firms, as well as for firms in other service sectors and industries (Yermack, 1996; Eisenberg et al., 1998; Guest, 2009; Fanta et al., 2013).

Thirdly, the size of the bank was seen to contribute positively to profitability and efficiency of operations. A larger sized bank was assumed to benefit from economies of scale (and reduced costs), and economies of scope (resulting in higher product diversification and better access to clients). With regard to effect on efficiency, the results were conflicting: lower costs were identified in both large (Altunbas et al., 2001; Berger \& Humphrey, 1997; Bikker \& Hu, 2002; Spathis et al., 2002; Srairi, 2009; Terraza, 2015) and small banks (Pallage, 1991; Vander Vennet, 1998; Kosmidou et al., 2006; Aladwan, 2015). As to profitability, the effect of the banks' sizes was contradictory too: whilst Ali et al. (2011) showed that bank size is positively related to bank profitability, Obamuyi (2013) demonstrated negative effects. Other researchers found limited influence of bank size on profitability (Berger et al., 1987; Boyd \& Runkle, 1993).

Fourthly, based on a theory of bank capital (Diamond \& Rajan, 2000), a positive relationship was hypothesized between bank capital and profitability, and between return on equity and capital-to-asset ratio, with banks being able to reduce bankruptcy risks and the need to rely on external funding sources. The hypothesis generally found support (Bourke, 1989; Liu \& Wilson, 2010; Goddard et al., 2004); however, Hughes and Mester (1998) established that a higher capital-to-assets ratio led to increased variable costs, and hence lower profitability.

Fifthly, with regard to the effect of operational expenses on profitability, the general view is that expense reduction tends to improve profitability (Bourke, 1989). However, if higher expenses are associated with payments to a more productive human capital (accumulated in human-capital intensive financial services), high costs may accompany high profitability (Molyneux \& Thornton, 1992). Research by Berger and Humphrey (1997), Berger and Mester (1997), Berger et al. (2000) and Francis (2013) appeared to confirm Bourke's hypothesis.

Sixthly, with regard to the external and macroeconomic determinants of profitability, a number of studies had been conducted. Guru et al. (2002) pointed to the negative effect of interest rates on bank profitability in Malaysia in 1986-95, whilst Chaudhry et al. (1995) outlined positive effects in the case of US banks in 1970-80s. With inflation determining the real value of costs and revenues, the ultimate effects of inflation (positive or negative) depend on whether inflation is anticipated or unanticipated (Perry, 1992). Positive effects of inflation on profitability were documented by Abreu and Mendes (2002) in the EU, and by Tan and Floros (2012) in China. Negative effects arising from the fact that banks do not recognize immediately that inflation has accelerated were identified by Boyd and Champ (2006). Several authors (Kosmidou et al., 2008, in the case of UK domestic commercial banks, and Al-Tamimi, 2006, in the case of UAE national banks) argued that macroeconomic and financial market conditions play a minor role in explaining bank performance, with internal variables being most salient.

Seventhly, a number of studies have considered banks' profitability in the market structure context. In line with the structure-conduct-performance hypothesis, higher banking concentration was attributed to higher market power and monopolistic profits (Hannan, 1979). In an oligopolistic setting, a positive relationship between formation banking cartels and 
collusion and profitability was identified, with collusion effectiveness being the highest when the number of banks colluding is small (Goddard et al., 2004). In a related vein, concentration and resulting higher market share were seen as lowering the costs of collusion and increasing profitability (Smirlock, 1985).

Finally, with regard to the effect of high credit risk on a bank's profitability and the associated issues of NPLs, a major hypothesis is that greater exposure of banks to high risk loans reduces profitability (Bourke, 1989; Miller \& Noulas, 1997): high risk leads to higher loan loss provisions, compromising banks' ability to follow profit-maximisation rules. Research on the credit risk-profitability relationship is scant, though several empirical studies appear to confirm the hypothesis (Sheefeni, 2015 in Namibia; Qin \& Pastory, 2012, in Tanzania; and Cimkono et al., 2016, in Malawi).

The literature pertaining specifically to Malaysian dualistic banking sector (composed of conventional commercial banks and interest-free Islamic banks operating in accordance with Sharia law) examined both the efficiency and profitability of the banks. The former stream of literature includes Sufian (2006) and Tahir et al. (2010), who examined the efficiency of the banks in a comparative setting (the analysis of efficiency in the different bank categories and in Malaysian versus foreign banks), and Zamil (2007) who examined the efficiency of the Islamic and non-Islamic commercial banks in 2000-2004, looking at various determinants of efficiency.

The latter aspect of the problem received much less analytical attention. The actual estimates of banking profitability were scarce, with the study by Ali Embaya (2013) a notable exception. For a sample of Malaysian Islamic banks in 2008-2010, the author documents a rather low level of returns on equity, ranging from an average of $2.89 \%$ in 2008 to an average of $3.49 \%$ in 2010, despite various positive developments in the Malaysian financial system in recent years.

With regard to the determinants of banking profitability, earlier studies included Haron (1997) and Guru et al. (2002). The scope of Haron's analysis however was limited to Islamic banks. Guru et al. (2002) considered a number of factors and argued that total expenditure to total assets variable had a negative impact on profitability, whereas current account deposits as a proportion of total assets had a positive effect. Loans and advances as a proportion of total assets had a positive effect on the return on assets and a negative effect on the return on equity. In addition, no significant relationship was found between capital and reserves, or time and savings deposits and bank profitability. Both papers relate to the period prior to the Asian crisis, and are hence outdated. In recent years, Sufian (2009) examined domestic and foreign commercial banks operating in Malaysia during 2000-04, and established that high credit risk and higher loan concentration have a negative effect on profitability, whilst the level of capitalization, non-interest income and operational expenses have a positive effect on profit levels. As to external macroeconomic variables, economic growth had a negative correlation with profitability, whilst the change in price level was positively correlated.

Jasmine et al. (2001) focused specifically on the period prior to, and the aftermath of the 2007-08 financial crisis, looking at eight major commercial banks. The determinants included gross domestic production, inflation rate, capital adequacy ratio, total income, expenses management, total loans, total deposits, and bank size. Only base lending rate, interest coverage, and capital adequacy ratio were found to be significant determinants of 
profitability, with all three factors having positive effects on profits. In a similar vein, Said and Tumin (2011) found no significant relationship between a bank's size and profitability.

With regard to institutional and regulatory influences, Sufian (2010), in a study covering 1992-2003, established that the extent of regulation and supervision had a negative effect on profitability levels. As to macroeconomic influences, while Jasmine et al. (2011) purport that there are no macroeconomic effects on profits, Sufian (2010) established positive effects of economic growth and inflation on profitability.

Overall, the literature on Malaysian banking sector profitability considers a substantial number of determinants and has yielded rather conflicting results. In addition, with the exception of Zamil (2007), who examined the effect of NPLs on banks' efficiency, analysis of the link between NPLs and bank performance has been lacking. In this connection, and also given that the post-GFC period differs from the pre-GFC one, or the period of the 1990s, it is instructive to re-examine the effects of NPLs along with other variables on the Malaysian banking sector using the most recent data.

\section{METHODOLOGY}

\subsection{Data Sources}

Eight Malaysian commercial banks (all listed on Malaysian stock exchange, Bursa Malaysia) have been chosen for this study: Affin Bank, Alliance Bank Malaysia, AmBank (M), CIMB Bank, Hong Leong Bank, Malayan Banking, Public Bank and RHB Bank.

The secondary data are obtained from different sources. The data for returns on equity, which is adopted as a measure of bank's profitability, has been obtained from the Thomson Reuters Datastream. The data for NPL, cost efficiency measure, and bank size measure have been collected from the annual reports of respective banks. The data for each variable covers the period of 2010-2015.

There are twenty seven commercial banks that operate in Malaysia (including affiliates of the US, French, Chinese and Japanese banking groups); however, only eight banks are listed on Bursa Malaysia. Their total capitalisation as of 31 December 2015 was US $\$ 59.17$ billion, constituting $15.5 \%$ of the total market capitalisation (US\$382.98 billion). Malayan Banking was the largest bank with capitalisation of US $\$ 18.79$ billion, while Affin Bank has the smallest capitalisation of US\$1.05 billion (Lim, Cheng, 2015).

\subsection{Econometric Model}

A panel data analysis (using pooled ordinary least squares (the OLS model)) is carried out, the sufficient degrees of freedom are ensured, and the properties of the data are considered (balanced panel with fixed panel data and the number of entities exceeding the number of observations, $n>T$ ). Specifically, the pooled ordinary least square model is used. For estimation purposes, the linear functional form is adopted, in line with prior studies of banking profitability (Molyneux et al., 1994; Lloyd-Williams et al., 1994). The following regression model is estimated and all of the sampled firms are pooled:

$$
\operatorname{PROF}_{i t}=\beta_{0}+\beta_{1} N P L R_{i t}+\beta_{2} \text { CIR }_{i t}+\beta_{3} \text { SSize }_{i t}+\varepsilon_{i t}
$$


Where PROF is a bank's profitability, NPLR is the non-performing loans (NPLs) ratio, CIR is cost-to-income ratio, LSize is the log of the total assets of the respective bank, $i$ and $t$ are subscripts representing bank and time, whilst $\varepsilon$ is the error term.

The dependent variable in this study is profitability as a measure of bank performance. Whilst several alternative measures of profitability are available, including return on assets (ROA) and return on equity (ROE), this study uses the latter indicator, consistent with previous studies (Ganesan, 2001; Fries, Taci, 2004; DeYoung, Rice, 2004). ROE is conceptualised as the measure of the bank's ability to generate profit from shareholders' invested capital, and is calculated as the ratio of net income to shareholders' equity (Gadoiu, 2014). In line with Molyneux and Thornton (1992), total equity was defined as the sum of shareholders' capital and undistributed net profit. Also, the end-of-the-year values of the equity were used (to account for the fact that the variable is not constant during the financial year), and the simple average was calculated for the two end-of-the-year values. Net income was defined as aftertax profit. Net income is derived from the bank's income statement, whilst the shareholder's equity of a bank is found in its balance sheet.

The independent variables in this study are NPLs, cost efficiency and bank size.

A NPL is defined as a loan that is unpaid by its debtor for at least 90 days and is either in default or close to the default point (Greenidge and Grosvenor, 2010), implying that the chances of the loan being paid in full are low. Clearly, the lending practices of the bank, as well as industry and macroeconomic conditions that affect borrowers' repayment abilities, determine the level of NPLs. In this study, NPL ratio is defined as the value of NPLs to total loans, i.e. is the value of NPLs divided by the value of total loans. We note that NPL is a regulatory concept and is different from alternative measures of credit risk and loannonperformance (Arpa et al., 2001; Bikker, Hu, 2002; Virolainen, 2004), such as accounting concepts of loan loss reserves and impaired loans (cases when it is probable that the creditor cannot collect the full amount of the loan), or risk management concepts, such as default rates. We further note that at present, no universally accepted measure of loan performance is available (Jakubík, Reininger, 2013).

Cost efficiency in this study is measured as operating cost to operating income ratio. Cost to income ratio is an efficiency measure that is similar to operating margin commonly used in the financial sector. Cost to income ratio is used to show the relation between a bank's expenses and its income. Operating cost or expenses generally includes expenses incurred from a bank or company's everyday activities expenses such as taxes, depreciation and rent, whereas operating income is equivalent to earnings before interest and tax (i.e. gross income minus operating expenses, depreciation and amortization).

Bank size in this study is approximated by the value of total assets of respective banks. Given the diverse sizes of the banks in the sample, the natural logarithm of the total assets was taken to obtain a meaningful figure for bank size.

Based on the literature review, the working hypotheses are: (1) there is a negative relationship between NPL ratio and ROE, and between cost-to-income ratio and ROE; and (2) there is an uncertain relationship between bank size and ROE. That is,

$$
\frac{\partial N P L R}{\partial P R O F}<0, \frac{\partial C I R}{\partial P R O F}<0 \text { and } \frac{\partial L \text { Size }}{\partial P R O F}>0 \text { or } \frac{\partial L \text { Size }}{\partial P R O F}<0
$$


The pooled OLS model was used to analyse the relationships between the variables. Firstly, the descriptive statistic of the dependent and independent variables were calculated. Secondly, diagnostic tests were carried out to determine the appropriate econometric method. Thirdly, a regression analysis using the pooled ordinary least squares (OLS) model was conducted to establish the relationships between dependent and independent variables and to confirm (reject) the hypotheses.

In this study, we acknowledge multiple causation channels between the variables, but do not attempt to establish which causation channel is predominant. Whilst the level of bad or nonperforming loans presumably negatively affects profitability, it is equally possible that a low level of profitability provides incentives to banks to engage in high-risk activities, thereby increasing NPL levels. Likewise, there is a relationship between inefficiency and poor use of assets, with low levels of ROA being accompanied by high levels of NPLs (Berger and DeYoung, 1997; Boudriga et al., 2009).

\section{EMPIRICAL ANALYSIS}

As a first step, descriptive statistics are presented (Table 1). The average return on equity for a sample of banks stood at $14.1 \%$, whilst the level of NPLs was small (on average $1.42 \%$ of the total loan portfolio). Operating costs were elevated relative to operating income, standing on average at $46.3 \%$ of the latter, and appeared to be a more pressing problem than loan performance. According to the Jarque-Bera test, the error terms of the model were normally distributed (JB statistics are 1.19, and the probability of getting these statistics under normal distribution assumptions is 0.55$)$.

Table 1. Descriptive Results

\begin{tabular}{|l|cccc|}
\hline Variable & ROE & NPL & Cost efficiency & Bank size \\
\hline Mean & 0.141 & 0.014 & 0.463 & 18.880 \\
Maximum & 0.253 & 0.033 & 0.602 & 20.377 \\
Minimum & 0.046 & 0.005 & 0.298 & 17.267 \\
Standard deviation & 0.041 & 0.008 & 0.081 & 0.847 \\
\hline Skewness & 0.753 & & & \\
Kurtosis & 0.309 & & & \\
JB & 1.190 & & & \\
Prob. (JB) & 0.553 & & & \\
\hline
\end{tabular}

Note: JB is Jarque-Bera test for normality, ROE is return on equity, NPL is the value of non-performing loans.

The Breusch-Pagan Lagrange Multiplier (LM) test for random effects was used to determine the appropriateness of the pooled OLS model versus random effects model (Breusch, Pagan, 1980). The consideration of the random effects model (as opposed to the fixed effects model) was dictated by the assumption that variation across entities is random and uncorrelated with regressors. The null hypothesis in the Breusch-Pagan LM test is that variances across entities are zero, i.e. there are no panel effects and substantial difference across entities. The rejection of the null hypothesis would imply random effects in the panel data and that the random effects model would deal with heterogeneity better than the pooled OLS. Test statistics with a p-value below conventional significance level (e.g. 5\%) would lead to rejection of the null, whilst the p-value exceeding the threshold would indicate failure to reject the null. 
Table 2. Breusch and Pagan Lagrangian Multiplier Test for Random Effects

\begin{tabular}{|lrr|}
\hline & Var & SD = Sqrt (Var) \\
ROE & 0.002 & 0.041 \\
$\mathrm{u}$ & 0.000 & 0.021 \\
\hline Test & 0.000 & 0.008 \\
\hline \multicolumn{2}{c|}{$\operatorname{Var}(\mathrm{u})=0$} \\
\hline \multicolumn{2}{c|}{$\mathrm{Chi}^{2}(1)=0.18$} \\
\hline Prob $>\mathrm{Chi}^{2}=0.6741$ \\
\hline
\end{tabular}

Source: authors

Table 2 above shows the result of the Breusch-Pagan (BP) test. The Breusch-Pagan test shows an insignificant $\mathrm{P}$-value more than 0.05 or $5 \%$, which indicates that the null hypothesis is not rejected and that the model appropriate for the study is the pooled OLS model.

Table 3. Diagnostic Tests

a). VIF (Tobin's Q Model)
Variable
NPL
Bank size
Cost efficiency
Mean VIF
b). Modified Wald test for groupwise heteroskedasticity
in fixed effect regression model
$\mathrm{H}_{0}:$ sigma(i) ${ }^{2}=$ sigma ${ }^{2}$ for all i
$\quad$ Chi ${ }^{2}(8)=27.080$
$\quad$ Prob $>$ Chi ${ }^{2}=0.0007$
c). Wooldridge test for autocorrelation in panel data
$\mathrm{H}_{0}:$ No first order autocorrelation
F $(1,7)=33.230$
Prob $>$ F $=0.0007$

Source: authors

A series of diagnostic tests were performed. Firstly, given that the number of banks exceeds the number of time periods, and that high correlation may exist between relevant independent variables, a test for multicollinearity was conducted. Variance inflation factors (VIFs) were obtained for all regressors, showing the extent of collinearity. As shown in Table 3, for each independent variable the level of VIF was below the conventional threshold of 10 . The mean VIF (equal to 1.08) was likewise below 10, indicating the absence of multicollinearity among independent variables.

Secondly, the Modified Wald test was used to detect heteroscedasticity problems. According to the results, the p-value of the Modified Wald test is less than 5\% significance level. Hence, the null hypothesis of no heteroscedasticity (constant variance) is rejected and there is a presence of a heteroscedasticity problem in the model. We note that in the previous research by Phun, Hirata and Yai (2013) and Tahir and Azid (2015), the problem of heteroscedasticity was solved using the method of the White robust standard error. 
Thirdly, the Wooldridge test was used to detect for autocorrelation. The p-value of the Wooldridge test is shown to be 0.0007 , i.e. below the $5 \%$ significance level, indicating that the null hypothesis of no autocorrelation was rejected and that autocorrelation was present in the model. Given that heteroscedasticity and autocorrelation were likely to cause bias in standard errors, the problem was solved in this study by obtaining Rogers (clustered) standard errors (Rogers, 1994).

Table 4. Findings of Regression Model

\begin{tabular}{|l|cccc|}
\hline \multicolumn{1}{|c|}{ Variables } & NPL & Cost Efficiency & Bank Size & Constant \\
\hline Coefficients & -0.7736 & -0.3622 & 0.0142 & 0.0516 \\
Standard Error (Robust) & 0.2169 & 0.0434 & 0.0061 & 0.1160 \\
t-statistics & -3.57 & -8.34 & 2.31 & 0.44 \\
P-value & $0.009^{* *}$ & $0.000^{*}$ & $0.054^{* * *}$ & 0.670 \\
\hline \# of observations & 48 & & & \\
F-statistic & 87.61 & & & \\
$\mathrm{R}^{2}$ & 0.65 & & & \\
\hline
\end{tabular}

Note: NPL is the value of non-performing loans. $(*),(* *)$ and $(* * *)$ represent significance at the $1 \%, 5 \%$ and $10 \%$ level.

Source: authors

Having made a correction for heteroscedasticity and autocorrelation, and ensured the normality of residuals and the absence of multicollinearity, the pooled OLS model was estimated. The results are presented in Table 4 and Equation (3) below.

$$
\begin{aligned}
R O E= & 0.0516-0.7736 N P L-0.3622 C I R+0.0142 L S i z e+\varepsilon_{t} \\
& (0.44) \quad(-3.57)
\end{aligned}
$$

It is shown that the model is correctly specified (F-statistic is 87.61). The overall explanatory power of the model (as measured by adjusted $\mathrm{R}^{2}$ ) is high, with $65 \%$ of the variation in the dependent variable being explained by the model, in line with the like bank profitability studies for other countries: Williams (1998) for Australia; Minh To and Tripe (2002) for New Zealand; and Staikouras and Wood (2003) and Pasiouras et al. (2006) for European economies. Robust standard errors allowed the taking into account of the heteroscedasticity and autocorrelation problem found in the regression model.

NPL has a coefficient of -0.7736 , a standard error of 0.2169 and a t-statistic of -3.57 (indicated in parethesis). The negative coefficient indicates that NPL has a negative relationship with return on equity (ROE). The respective p-value of NPL was found to be significant, at a 5\% significance level. The negative sign indicates that when the NPL of a commercial bank increases, the profitability of the commercial bank decreases. Thus, NPL is found to be a factor that causes deterioration in bank performance. The negative relationship between NPL and bank profitability in terms of ROE is consistent with Berger, 1995; Demirguc-Kunt and Huizinga, 1999; Ben Nacuer, 2003; Pasiouras and Kosmidou, 2007; Pasiouras et al., 2006; as well as recent study conducted by Sheefeni (2015) in Namibia.

As for cost efficiency, Table 4 shows that the coefficients, the standard error and t-statistic of cost efficiency are $-0.3622,0.0434$ and -8.34 respectively. The negative coefficient of cost efficiency similar to NPL shows that there is a negative relation between cost efficiency and ROE as well. Cost efficiency's p-value is shown to be at a $1 \%$ significance level, indicating 
that cost efficiency has a significant effect on ROE. When cost efficiency of the commercial banks increases by $1 \%$, ROE decreases by $36.22 \%$. The negative association between cost efficiency and ROE in terms of profitability is also consistent with Guru et al. (2002), Kosmidou (2008) and Pasiouras et al. (2006), and recent studies by Mathuva (2009) and Francis (2013).

The coefficients, the standard error and t-statistic of bank size are 0.0142, 0.0061 and 2.31 respectively. Unlike NPL and cost efficiency, bank size is found to have a positive impact on ROE of commercial banks at a $10 \%$ significance level, with ROE of commercial banks increasing by $1 \%$, when the logarithm of the commercial bank size increases by $1.42 \%$. Thus, bank size is found to have a positive impact on bank performance in Malaysia, with larger banks earning higher margins and profits, suggesting either diseconomies of scale/scope for smaller banks or economies for larger banks. This contravenes the earlier study by Kosmidou et al. (2006) that examined performance of the UK banks in 1998-2002 and that found significant diseconomies of scale, as well as the study conducted by Vander Vennet (1998) on a sample of European financial conglomerates and universal banks, that established economies of scale for the smallest banks with assets under ECU 10 billion and diseconomies of scale for the largest banks with over ECU 100 billion in assets. On the other hand, our results confirm the studies by Bourke (1989), Bikker \& Hu (2002), Srairi (2009) and Terraza (2015), as well as results of the study of profitability of Greek banks in 1990-1999 by Spathis et al. (2002).

As part of the robustness check and given that some variation of ROE is not explained by the model with three regressors, additional independent variables are introduced. Specifically, we included debt ratio (defined as the ratio of total liabilities to total assets) for individual banks, as well as the inflation rate and the base lending rate. Debt ratio was calculated using banks' financial statements, where as inflation and interest rate figures were obtained from Bank Negara Malaysia.

As a first step, regression with all relevant variables was estimated. Results are presented below (Equation 4).

$$
\begin{aligned}
& R O E=0.503-1.047 N P L-0.378 C I R+0.013 L \text { Size }+0.025 D R-6.684 B L R+1.033 I N F+\varepsilon_{t}(4) \\
& (3.35) \quad(-2.08) \quad(-6.79) \quad(2.75) \quad(1.36) \\
& R^{2}=0.707, F-\text { statistic }=19.93, J B=2.268(p=0.322)
\end{aligned}
$$

The inclusion of additional variables improved the predictive power of the model, with $\mathrm{R}^{2}$ increasing from $65 \%$ to $71 \%$. Two of the additional variables (base lending rate and inflation rate) are statistically significant at $5 \%$ and $10 \%$ level, while debt ratio is not significant at any conventional significance levels. The signs of variables are expected - positive for the logarithm of the bank size, debt ratio, and inflation rate; and negative for the non-performing loans ratio and cost efficiency ratio.

The sign of inflation rate coefficient is positive, indicating that commercial banks in question anticipated increase in consumer price, i.e. they were able to adjust bank rates so that bank revenues increase at a faster rate than costs. 
The sign of debt ratio coefficient is positive as well, suggesting that core activities of the banks (lending to firms and households) continue to be an important source of income to the bank (in addition to alternative bank outputs - investments and securities).

The sign of the interest rate coefficient is negative, implying that increase in the level of interest rates has adverse effects on banks' profitability. This may seem to contravene existing theoretical and empirical studies (Shiller, McCulloch, 1987; Chaudhry et al., 1995; Borio et al., 2015). However, as argued by Aydemir and Ovenc (2016) in the context of profitability of Turkish banks, the negative effects may be explained by pricing frictions, when banks are not able to adjust deposit and loan rates to changes in interest rates sufficiently fast. In addition, the traditional interest income channel (through which interest rate affects profitability) may be weakened in modern banking, given that banks rely progressively more on non-interest income (fees and commissions).

Secondly, given that debt ratio coefficient is not significant, regression model excluding debt ratio was estimated. Results are shown as follows, and are in line with estimates contained in Equations (3) and (4). All variables are significant and have correct signs.

$$
\begin{aligned}
& R O E=0.515-1.297 N P L-0.327 C I R+0.016 L \text { Size }-7.996 B L R+1.192 I N F+\varepsilon_{t} \\
& (3.40) \quad(-2.74) \quad(-7.86) \quad(3.83) \quad(-3.64)
\end{aligned}
$$

\section{CONCLUSIONS}

This study aimed to improve understanding of the driving forces of commercial banks' performance in Malaysia, specifically examining the link between non-performing loans (NPLs), cost efficiency and bank size and bank profitability. It was shown that there is a negative relationship between NPLs and bank profitability, and between cost-to-income ratio and profitability, and a positive relationship between bank size and profitability. The results are largely in line with those of the extant literature.

These results confirm the insights the inability of banking firms with large proportion of NPLs in their total loan portfolios to profit-maximise, and points to the underlying problem of adverse selection: given the inherent difficulty in discrimination between good and bad borrowers, the levels of NPLs can potentially increase when bad borrowers are chosen instead of the good ones, thereby leading to deterioration in profitability. Regarding the cost-profit relationship, the findings confirm the hypothesis of the negative effects of operational costs on profits. The effect of high payments for human capital (human capital costs) moving in tandem with profitability was not identified. As for bank size, the findings supported the structure-conduct-performance hypothesis, whereby the size of the bank allows it to capture a higher market share and earn greater profits. Whether there is collusion or cartelization among Malaysian banks is a topic that requires investigation on its own.

The results have several implications for business strategy and banking and prudential regulation. Given the negative relationship established between NPLs and bank profitability, it is of the utmost importance that banks focus on credit risk management. Banks should be wary of approving loans to borrowers that are capable of paying them back, should keep the amount of NPLs within limits, and should create sufficient reserves for writing off impaired loans. Improvement in asset quality is equally important, specifically resulting from the reduction and minimization of loan provision to and investment in cyclical and volatile 
sectors (real estate and energy), overseas businesses (e.g. subsidiaries that Malaysian banks have little ability to supervise or manage), or financial instruments (in which Malaysian commercial banks have little expertise). As a systemic response, regulators are advised to improve the overall transparency of the financial system, through fostering improvements in corporate governance, accounting standards, and the like.

Given the negative association between cost efficiency and bank performance, the management of costs will remain an area of concern. In addition to direct cost control measures, indirect ways may come to forefront, e.g. an increase in current account deposits and more aggressive marketing of such products to enhance revenues. In terms of bank size, regulators may refrain from attempts to enact greater competition in the sector or to break up the biggest players, in line with the Chicago school of antitrust analysis (Posner, 1976).

The sample of banks was limited to eight commercial banks listed on Bursa Malaysia, and thus excluded foreign and unlisted banks. Thus, the findings of this study may not be applicable for the banks in these categories. The sample period was limited to post-GFC years; thereby comparative analysis of bank profitability prior to and after GFC is precluded.

There are several avenues for future research. Firstly, the estimates may be performed on a longer sample, possibly including structural breaks for GFC years. Similarly, a comparative analysis of banks' profitability may be performed, including other South-East Asian economies, economies with similar regulatory and prudential systems, or economies with development levels (including level of financial development) similar to Malaysia. Secondly, in addition to ROE, alternative dependent variables may be used, including return on assets (ROA), as well as net interest margin (NIM), defined as a ratio of net interest income to earning assets, thereby showing the profitability of the bank's interest-earning business. Thirdly, in addition to NPLs, various measures of liquidity, asset quality or capital strength may be used (e.g. ratio of liquid assets to customer and short-term funding, ratio of loan loss reserves to gross loans, or ratio of equity to total assets). Fourthly, while this study focused on internal determinants of profitability, it is possible to reconsider the effects of GDP growth, anticipated and unanticipated inflation, and interest rates. An analysis of the effect of industry structure on banking profitability may also be undertaken, with various concentration measures included as regressors.

Finally, a qualitative analysis may serve as a complement to conventional regression models of profitability, given the nature of Malaysian capitalism in general and the banking sector in particular. Many banks benefit from a competitive advantage due to preferential relations with government, specific customer relations and corporate image. In addition, the incorporation of banks' intangible assets and goodwill into the measure of profitability may be required to fully capture the asset base of the banks.

\section{ACKNOWLEDGEMENTS}

Authors acknowledge the support by University of Malaysia, Sarawak (UNIMAS Special Short Term Grant - F01/SpSTG/1574/2017). 


\section{REFERENCES}

Abd Karim, M. Z., Sok, G. C., \& Hassan, S. (2010). Bank efficiency and non-performing loans: Evidence from Malaysia and Singapore. Prague Economic Papers, 2, 118-132. https://doi.org/10.18267/j.pep.367

Abreu, M. \& Mendes, V. (2002). Commercial bank interest margins and profitability: Evidence from E.U. countries. University of Porto Working Paper Series No. 122.

Afanasieff, T., Lhacer P. \& Nakane M. (2002). The determinants of bank interest spreads in Brazil. Central Bank of Brazil, Research Department, Working Paper Series No. 46.

Aladwan, M. S. (2015). The impact of bank size on profitability: An empirical study on listed Jordanian commercial banks. European Scientific Journal, 11(34), 217-236.

Ali, K., Akhtar, M. F., \& Ahmed, H. Z. (2011). Bank-specific and macroeconomic indicators of profitability: Empirical evidence from the commercial banks of Pakistan. International Journal of Business and Social Science, 2(6), 235-242.

Altunbas, Y., Gardener, E. P. M., Molyneux, P., \& Moore, B. (2001). Efficiency in European banking. European Economic Review, 45(10), 1931-1955. https://doi.org/10.1016/S0014-2921(00)00091-X

Al-Tamimi, H. A. (2006). The determinants of the UAE commercial banks' performance. Journal of Transnational Management, 10(4), 35-47. https://doi.org/ 10.1300/J482v10n04_03

Arpa, M., Giulini, I., Ittner, A. \& Pauer, F. (2001). The influence of macroeconomic developments on Austrian banks: Implications for banking supervision. In Arpa M. et al. (Eds), BIS papers chapters, volume 1 (pp. 91-116). Basel: Bank of International Settlements.

Aydemir, R., \& Ovenc, G. (2016). Interest rates, the yield curve and bank profitability in an emerging market economy. Economic Systems, 40(4), 670-682. https://doi.org/10.1016/j.ecosys.2016.04.003

Barajas, A., Steiner R., \& Salazar N. (1999). Interest spreads in banking in Colombia, 1974-96. IMF Staff Papers, 46(2), 196-224. https://doi.org/10.2307/3867667

Beck, T., Cull, R., \& Afeikhena, J. (2005). Bank privatization and performance: Empirical evidence from Nigeria. Journal of Banking and Finance, 29(8-9), 2355-2379. https://doi.org/10.1016/j.jbankfin.2005.03.018

Ben Naceur, S. (2003). The determinants of the Tunisian banking industry profitability: Panel evidence. Paper Presented at the Economic Research Forum (ERF) 10th Annual Conference, Marrakesh-Morocco, 16-18 December.

Berger, A.N. (1995). The relationship between capital and earnings in banking, Journal of Money, Credit and Banking, 27(2), 432-456. https://doi.org/10.2307/2077877

Berger, A.N., Hanweck, G. A., \& Humphrey, D. B. (1987). Competitive viability in banking: Scale, scope and product mix economies. Journal of Monetary Economics, 20(3), 501-20. https://doi.org/10.1016/0304-3932(87)90039-0

Berger, A. N., \& DeYoung, R. (1997). Problem loans and cost efficiency in commercial banks. Journal of Banking and Finance, 21(6), 849-870. https://doi.org/10.1016/S03784266(97)00003-4

Berger, A.N., \& Humphrey, D.B. (1997). Efficiency of financial institutions: International survey and directions for future research, European Journal of Operational Research, 98(2), 175-212. https://doi.org/10.1016/S0377-2217(96)00342-6

Berger, A. N., \& Mester, L. (1997). Inside the black box: What explains differences in the efficiencies of financial institutions. Journal of Banking and Finance, 21(7), 895-947. https://doi.org/10.1016/S0378-4266(97)00010-1 
Berger, A. N., DeYoung, R., Genay, H., \& Udell, G. (2000). Globalization of financial institutions: Evidence from cross-border banking performance. Brookings-Wharton Papers on Financial Services, 3, 23-158. http://dx.doi.org/10.2139/ssrn.203509

Bikker, J. A., \& Hu, H. (2002). Cyclical patterns in profits, provisioning and lending of banks and procyclicality of the new Basle capital requirements. BNL Quarterly Review, 55(221), 143-175.

Borio, C., Gambacorta, L. \& Hofmann, B. (2015). The influence of monetary policy on bank profitability. Bank of International Settlements Working Paper No. 514.

Boudriga, A., Boulila, N., \& Jellouli, S. (2009). Does bank supervision impact nonperforming loans: Cross-country determinants using aggregate data? (MPRA Paper No. 18068).

Bourke, P. (1989). Concentration and other determinants of bank profitability in Europe, North America and Australia. Journal of Banking \& Finance, 13(1), 65-79. https://doi.org/10.1016/0378-4266(89)90020-4

Boyd, J., \& Runkle, D. (1993). Size and performance of banking firms: Testing the predictions theory. Journal of Monetary Economics, 31(1), 47-67. https://doi.org/ 10.1016/0304-3932(93)90016-9

Boyd, J. H. \& Champ, B. (2006). Inflation, banking and economic growth. Federal Reserve Bank of Cleveland, Economic Commentary, 15 May 2016.

Breusch, T., \& Pagan, A. (1980). The LM test and its applications to model specification in econometrics. The Review of Economic Studies, 47(1), 239-253. DOI: 10.2307/2297111

Chaudhry, M., Chatrath, A., \& Kamath, R. (1995). Determinants of bank profitability. American Journal of Business, 10(1), 41-46. https://doi.org/10.1108/193551811995 00005

Cimkono, E. E., Muturi, W., \& Njeru, A. (2016). Effect of non-performing loans and other factors on performance of commercial banks in Malawi. International Journal of Economics, Commerce and Management, 4(2), 549-563.

Demirguc-Kunt, A., \& Huizinga, H. (1999). Determinants of commercial bank interest margins and profitability: Some international evidence, World Bank Economic Review, 13(2), 379-408.

DeYoung, R., \& Rice, T. (2004). Non-interest income and financial performance at US commercial banks. The Financial Review, 39(1), 101-127. https://doi.org/10.1111/ j.0732-8516.2004.00069.x

Diamond, W. D., \& Rajan, G. R. (2000). A theory of bank capital. Journal of Finance, 55(6), 2431-2465. https://doi.org/10.1111/0022-1082.00296

Dietrich, A., \& Wanzenried, G. (2011). Determinants of bank profitability before and during the crisis: Evidence from Switzerland. Journal of International Financial Markets, Institutions and Money, 21(3), 307-327. https://doi.org/10.1016/j.intfin.2010.11.002

Drake, L. (2001). Efficiency and productivity change in UK banking. Applied Financial Economics, 11(5), 557-571. https://doi.org/10.1080/096031001752236825

Eisenberg, T., Sundgren, S., \& Wells, M. T. (1998). Larger board size and decreasing firm value in small firms. Journal of Financial Economics, 48(1), 35-54. https://doi.org/ 10.1016/S0304-405X(98)00003-8

Fanta, B. A., Kemal, S. K., \& Waka, K. Y. (2013). Corporate governance and impact on bank performance. Journal of Finance and Accounting, 1(1), 19-26. https://doi.org/ 10.11648/j.jfa.20130101.12

Francis, M. E. (2013). Determinants of commercial bank profitability in Sub-Saharan Africa. International Journal of Economics and Finance, 5(9), 134-147.

Fries, S., \& Taci, A. (2004). Cost efficiency of banks in transition: Evidence from 289 banks in 15 post-communist countries. Journal of Banking and Finance, 29(1), 55-81. https://doi.org/10.1016/j.jbankfin.2004.06.016

Gadoiu, M. (2014). Advantages and limitations of the financial ratios used in the financial diagnosis of the enterprise. Scientific Bulletin-Economic Sciences, 13(2), 87-95. 
Ganesan, P. (2001). Determination of profits and profitability of public section banks in India: A profit function. Journal of Financial Management and Analysis, 14(1), 27-37.

Goddard, J., Molyneux, P., \& Wilson, J. O. S. (2004). The profitability of European banks: A cross-sectional and dynamic panel analysis. The Manchester School, 72(3), 363-381. https://doi.org/10.1111/j.1467-9957.2004.00397.x

Greenidge, K., \& Grosvenor, T. (2010). Forecasting non-performing loans in Barbados. Journal of Business, Finance and Economics in Emerging Economies, 5(1), 80-107.

Grigorian, D., \& Manole, V. (2006). Determinants of commercial bank performance in transition: An application of data envelopment analysis. Comparative Economic Studies, 48(3), 497-522.

Guest, P. M. (2009). The impact of board size on firm performance: Evidence from the UK. European Journal of Finance, 15(4), 385-404. http://dx.doi.org/10.1080/ 13518470802466121

Guru, B., Staunton. J. \& Balashanmugam, B. (2002). Determinants of commercial bank profitability in Malaysia. Paper presented at the 12th Annual Australian Finance and Banking Conference, Sydney, Australia, 16-17 December 2002.

Hannan, T. (1979). Limit pricing and the banking industry. Journal of Money, Credit, and Banking, 11(4), 438-46. http://dx.doi.org/10.2307/1992045

Haron, S. (1997). Determinants of Islamic bank profitability: Some evidence. Jurnal Pengurusan, 16(1), 33-46.

Hassan, M.K. \& Bashir, A-H.M. (2003). Determinants of Islamic banking profitability, Paper Presented at the Economic Research Forum (ERF) $10^{\text {th }}$ Annual Conference, MarrakeshMorocco, 16-18 December.

Hughes, J. P., \& Mester, L. J. (1998). Bank capitalization and cost: Evidence of scale economies in risk management and signaling. The Review of Economics and Statistics, 80(2), 314-325. https://doi.org/10.1162/003465398557401

Jakubík, P., \& Reininger, T. (2013). Determinants of nonperforming loans in Central, Eastern and Southeastern Europe. Focus on European Economic Integration, Oesterreichische Nationalbank, 3, 48-66.

Jasmine, E., Yen Yi, K., Yun Xi, S., Mohanen, S. \& Ding, T. J. (2011). An empirical analysis of commercial banks' profitability determinants in Malaysia after the 2008 financial crisis. (Unpublished Manuscript, Tunku Abdul Rahman University). Retrieved from http://eprints.utar.edu.my/459/

Jokipii, T., \& Monnin, P. (2013). The impact of banking sector stability on the real economy. Journal of International Money and Finance, 32(1), pp. 1-16. https://doi.org/ 10.1016/j.jimonfin.2012.02.008

Khoon, G. \& Mah-Hui, M. (2010). The impact of the global financial crisis: The case of Malaysia. Third World Network Global Economy Series No 26, Third World Network: Penang.

Klein, P-O. \& Weill, L. (2017). Bank profitability: Good for growth? University of Strasbourg, LaRGE Research Centre Working Paper, 2017-02.

Kosmidou, K., (2008), The determinants of banks' profits in Greece during the period of EU financial integration. Managerial Finance, 34(3), 146-159. https://doi.org/ 10.1108/03074350810848036

Kosmidou, K., Pasiouras, F., Doumpos, M., \& Zopounidis, C. (2006). Assessing performance factors in the UK banking sector: A multicriteria approach. Central European Journal of Operations Research, 14(1), 25-44.

Kosmidou, K., Tanna, S. \& Pasiouras, F. (2008). Determinants of profitability of domestic UK commercial banks: Panel evidence from the period 1995-2002. Coventry University Business School, Economics, Finance and Accounting Applied Research Working Paper Series No. RP08-4. 
Lim, S., \& Cheng, L. (2015). Malaysia Industry Focus, Malaysian Banks. Singapore: DBS Group Research.

Liu, H., \& Wilson, J. O. S. (2010). The profitability of banks in Japan. Applied Financial Economics, 20(24), 1851-1866. https://doi.org/10.1080/09603107.2010.526577

Lloyd-Williams, D. M., Molyneux, P., \& Thornton, J. (1994). Market structure and performance in Spanish banking. Journal of Banking and Finance, 18(3), 433-443. https://doi.org/10.1016/0378-4266(94)90002-7

Mathuva, D. M. (2009). Capital adequacy, cost income ratio and the performance of commercial banks: The Kenyan scenario. The International Journal of Applied Economics and Finance, 3(2), 35-47. https://doi.org/10.3923/ijaef.2009.35.47

Miller, S., \& Noulas, A. (1997), Portfolio mix and large-bank profitability in the USA. Applied Economics, 29(4), 505-12. https://doi.org/10.1080/000368497326994

Minh To, H., \& Tripe, D. (2002). Factors influencing the performance of foreign-owned banks in New Zealand. Journal of International Financial Markets, Institutions and Money, 12(4-5), 341-57. https://doi.org/10.1016/S1042-4431(02)00018-5

Molyneux, P., \& Thorton, J. (1992). The determinants of European bank profitability. Journal of Banking and Finance, 16(6), 1173-1178. https://doi.org/10.1016/03784266(92)90065-8

Molyneux, P., Lloyd-Williams, D. M., \& Thornton, J. (1994). Competitive conditions in European banking. Journal of Banking and Finance, 18(3), 445-459. https://doi.org/ 10.1016/0378-4266(94)90003-5

Obamuyi, T. M. (2013). Determinants of bank's profitability in a developing economy: Evidence from Nigeria. Organizations and Markets in Emerging Economies, 4(2), 97111.

Pallage, S. J. (1991). An econometric study of the Belgian banking sector in terms of scale and scope economies. Cahiers Economiques de Bruxelles, 130, 126-143.

Pasiouras, F., \& Kosmidou, K. (2007). Factors influencing the profitability of domestic and foreign banks in the European Union. Research in International Business and Finance, 21(2), 222-237. https://doi.org/10.1016/j.ribaf.2006.03.007

Pasiouras, F., Kosmidou K. \& Gaganis, Ch. (2006). A pooled study of the internal and external determinants of Australian banks' profits and margins. Technical University of Crete, Working Paper, Financial Engineering Laboratory.

Phun, V. K., Hirata, T., \& Yai, T. (2013). Analysis of acceptable flight frequency under the effects of other people's noise-situations. Journal of the Eastern Asia Society for Transportation Studies, 10, 2147-2160.

Posner, R. (1976). Antitrust law: An economic perspective. Chicago: The University of Chicago Press.

Qin, X., \& Pastory, D. (2012). Commercial banks profitability position: The case of Tanzania. International Journal of Business and Management, 7(13), 136-144. http://dx.doi.org/ 10.5539/ijbm.v7n13p136

Rogers, W. (1994). Regression standard errors in clustered samples. Stata Technical Bulletin, 3(13), 19-23.

Said, R., \& Tumin, M. (2011). Performance and financial ratios of ommercial banks in Malaysia and China. International Review of Business Research Papers, 7(2), 157-169.

Sheefeni, J. P. S. (2015). Evaluating impact of bank specific determinants of non-performing loans in Namibia. Journal of Emerging Issues in Economics, Finance and Banking, 4(2), 1525-1541.

Shiller, R. \& McCulloch, J. (1987). The term structure of interest rates. National Bureau of Economic Research. Cambridge, Massachusetts.

Smirlock, M. (1985). Evidence of the (non) relationship between concentration and profitability in banking. Journal of Money, Credit, and Banking, 17(1), 69-83. https://doi.org/10.2307/1992507 
Spathis, Ch., Kosmidou K., \& Doumpos, M. (2002). Assessing profitability factors in the Greek banking system. International Transactions in Operational Research, 9(5), 517-530. https://doi.org/10.1111/1475-3995.00371

Srairi, S. A. (2009). Factors influencing the profitability of conventional banks and Islamic banks in GCC countries. Review of Islamic Economics, 13(1), 5-30.

Staikouras, Ch., \& Wood, G. (2003). The determinants of bank profitability in Europe. Paper Presented at the European Applied Business Research Conference, Venice, Italy, 9-13 June.

Standard and Poors (2017). Malaysian banks' credit profiles remain stable but underlying risks linger. S\&P Global Ratings, Singapore.

Sufian, F. (2006). Size and returns to scale of the Islamic banking industry in Malaysia: Foreign versus domestic banks. Journal of Economics and Management, 14(2), 147175.

Sufian, F. (2009). Factors influencing bank profitability in a developing economy. Empirical evidence from Malaysia. Global Business Review, 10(2), 225-241. https://doi.org/ $10.1177 / 097215090901000206$

Sufian, F. (2010). Developments in the performance of the Malaysian banking sector: Opportunity cost of regulatory compliance. International Journal of Business Competition and Growth, 1(1), 85-103. https://doi.org/10.1504/IJBCG.2010.032830

Tahir, I., Abu Bakar, N. M., \& Haron, S. (2010). Cost and profit efficiency of the Malaysian commercial banks: A comparison between domestic and foreign banks. International Journal of Economics and Finance, 2(1), 186-197.

Tahir, M., \& Azid, T. (2015). The relationship between international trade openness and economic growth in the developing economies: Some new dimensions. Journal of Chinese Economic and Foreign Trade Studies, 8(2), 123-139. https://doi.org/ 10.1108/JCEFTS-02-2015-0004

Tan, Y., \& Floros, C. (2012). Bank profitability and inflation: The case of China. Journal of Economic Studies, 39(6), 675-696. https://doi.org/10.1108/01443581211274610

Terraza, V. (2015). The effect of bank size on risk ratios: Implications of banks' performance. Centre for Research in Economics and Management (CREA), University of Luxembourg, Working Paper.

Vander Vennet, R. (1998). Cost and profit dynamics in financial conglomerates and universal banks in Europe. Paper Presented at the Societe Universitaire Europeenee de Recherchers Financiers/CFS colloquium, Frankfurt, 15-17 October.

Virolainen, K. (2004). Macro stress testing with a macroeconomic credit risk model for Finland. Bank of Finland Discussion Papers, 18, 1-45.

Webb, R. M. (2003). Levels of efficiency in UK retail banks: A DEA window analysis. International Journal of the Economics of Business, 10(3), 305-322. https://doi.org/10.1080/1357151032000126256

Williams, B. (1998). Factors affecting the performance of foreign-owned banks in Australia: A cross-sectional study. Journal of Banking and Finance, 22(2), 197-219. https://doi.org/10.1016/S0378-4266(97)00054-X

Yermack, D. (1996). Higher market valuation of companies with a small board of directors. Journal of Financial Economics, 40(2), 185-211. https://doi.org/10.1016/0304405X(95)00844-5

Zamil, N. A. (2007). Efficiency of Islamic and conventional commercial banks in Malaysia (2000-2004): A data envelopment analysis (DEA) study. (Unpublished Dissertation, International Islamic University Malaysia). Retrieved from https://lib.iium.edu.my /mom/services/mom/document/getFile/uNAaq66dsOLGMs3rEPZAZoE7WDimgIZm20 071214083548906 